\title{
Ethnologies
}

\section{The Celebration of Cultural Diversity and the Politics of Difference in Safeguarding Intangible Cultural Heritage}

\author{
Antonio A. Arantes
}

Volume 36, numéro 1-2, 2014

Patrimoine culturel immatériel

Intangible Cultural Heritage

URI : https://id.erudit.org/iderudit/1037610ar

DOI : https://doi.org/10.7202/1037610ar

\section{Aller au sommaire du numéro}

\section{Éditeur(s)}

Association Canadienne d'Ethnologie et de Folklore

ISSN

1481-5974 (imprimé)

1708-0401 (numérique)

Découvrir la revue

Citer cet article

Arantes, A. A. (2014). The Celebration of Cultural Diversity and the Politics of Difference in Safeguarding Intangible Cultural Heritage. Ethnologies, 36(1-2), 279-296. https://doi.org/10.7202/1037610ar
Résumé de l'article

Au niveau mondial, le changement d'attitude au sujet de la production culturelle a conféré une nouvelle signification aux objets et aux idées qui véhiculent un sens du lieu et/ou de la singularité culturelle, en même temps qu'il a éveillé l'intérêt public et le souci des institutions d'en faire l'inventaire et de protéger la diversité culturelle. Les implications de ce revirement ne concernent pas uniquement ce que l'on appelle les industries créatives, car cette question faisait l'objet de la Convention sur la protection et la promotion de la diversité des expressions culturelles entérinée par l'UNESCO lors de sa 33e conférence générale (Paris, novembre 2005). Le savoir-faire et les formes d'expressions traditionnelles, ainsi que les paysages exotiques, ont efficacement joué le rôle de pierres de touche dans la mise en oeuvre et la valorisation de programmes de développement humain, autant que social et économique, dans les régions les plus pauvres de la planète. D'un point de vue intellectuel, cet intérêt renouvelé pour tout ce qui est local incite à la réflexion critique au sujet de certaines questions épistémologiques et juridiques en lien avec l'identification, la documentation et la valorisation du patrimoine culturel. Parmi celles-ci, l'autorité intellectuelle associée à la production d'inventaires, les conséquences sociales de l'introduction de nouveaux éléments dans les politiques de niveau local et la production culturelle, ainsi que les problèmes juridiques relatifs aux droits collectifs de propriété intellectuelle, constituent quelques-uns des axes du débat actuel entre chercheurs et experts du patrimoine. Cet article apporte sa contribution à ce débat sur les questions énumérées ci-dessus, en se concentrant sur les politiques émergentes de sauvegarde du patrimoine culturel immatériel. Le patrimoine culturel n'étant pas une transmission mécanique et neutre d'informations d'une génération à l'autre, mais une construction sociale, comprendre ses significations et ses conséquences implique de prendre en compte son contexte historique. Ceci étant, afin de procurer une base concrète à cette discussion, l'auteur évoque le cas brésilien, celui-ci suggérant toutefois que les implications pourraient être de plus grande ampleur.
Ce document est protégé par la loi sur le droit d'auteur. L’utilisation des services d’Érudit (y compris la reproduction) est assujettie à sa politique d'utilisation que vous pouvez consulter en ligne.

https://apropos.erudit.org/fr/usagers/politique-dutilisation/ 


\title{
The Celebration of Cultural Diversity and the Politics of Difference in Safeguarding Intangible Cultural Heritage
}

\author{
Antonio A. Arantes \\ UNICAMP - State University of Campinas
}

The construction of social memory and the preservation of cultural heritage are closely related practices concerning the reproduction of social life. Both create affective and cognitive landmarks, providing shared references to historical change and continuity. However, one major difference between them lies in the fact of whether such landmarks are recognized beyond the limits of the cultural history of specific social groups and if they effectively participate in the processes of social identification that underlies the formation of hegemonies and of national cultures. While the former mainly concern social agencies and actors belonging to specific social milieux, the latter is a specialized activity that necessarily involves professionals, experts, governmental agencies, regional and multilateral organizations and NGOs whose institutional cultures, political commitments and economic priorities may differ from - and sometimes are in conflict with - local social realities. The nature and complexity of the gap between such inner and outer cultural, political and economic domains tend to vary widely and become particularly complex depending on the values attached to cultural diversity in the social environments concerned. This is often the case when officially protected heritage is built on the basis of popular and indigenous cultural practices.

The global turn of cultural production gave new significance to objects and ideas that convey senses of localization and/or cultural singularity, raising public interest and institutional concern with inventorying and protecting cultural diversity. The implications of this shift not only concern the so-called creative industries, as this issue was the object of the Convention for the Protection of the Diversity of Cultural Contents and Artistic Expressions approved by UNESCO in its $33^{\text {rd }}$ General Conference 
(Paris, November 2005). Traditional know-how and forms of expression, as well as exotic landscapes, are used as effective cornerstones for the implementation and promotion of humanitarian as well as social and economic development programs in the poorer regions of the globe. From an intellectual perspective, this renewed awareness of all things local stimulates critical reflection about some epistemological and legal issues related to identification, documentation and promotion of cultural heritage. Among these, intellectual authority associated with the production of inventories, the social consequences of introducing new ingredients in local level politics and cultural production, as well as juridical matters concerning rights of collective intellectual property are some of the headlines of the current debate among scholars and heritage experts on those issues.

The present paper aims at contributing to the debate on the questions outlined in these brief introductory remarks, by focusing the emergent policies of safeguarding intangible cultural heritage. Since cultural heritage is not mechanical and neutral transmission of information from one generation to another, but a social construction, the understanding of its meanings and consequences depends on taking into account its historical context. This being the case, in order to provide concrete background to this discussion, I will refer to the Brazilian case suggesting, however, that it has wider implications.

\section{Cultural preservation and the formation of a cultural global public sphere}

The formation of preservation institutions and the designing of safeguarding policies tend to respond to local needs, constraints and timing, and these may vary - and do so greatly - from one part of world to another. National or regional differences are realities that clearly come to the fore in international expert meetings on this matter. But it is also apparent that a worldwide agenda is being matured and that national or local institutions are progressively being challenged to respond to those internationally negotiated parameters.

The safeguarding of intangible cultural heritage is one of the emergent areas leading to the formalization of internationally agreed policy aims and principles. Unesco has been historically the core institution in the formation of such 'global cultural public sphere' for heritage matters, as it involves and mobilizes representatives of that organization's member states, as well as NGOs and experts from around the world. WIPO, in 
its turn, plays a complementary role in this matter, as a forum for the negotiation of international commercial recommendations, agreements and conventions regarding the legal protection of traditional knowledge and cultural expressions. Regional governmental networks, in their turn, such as the Community of the Portuguese Speaking Countries - CPLP, Mercosul, as regards Latin America, and agencies such as the Asia/Pacific Cultural Center for UNESCO - ACCU also contribute significantly to consolidating the international networks of experts and institutions that give effectiveness to such multilateral agreements.

A very positive outcome of this process is that heritage is in the process of becoming part of an international agenda that is critical of some drawbacks of globalization, for example, the concentration of power and resources (both material and intellectual) in certain parts of the world, and engaged in questions, such as fighting poverty and social exclusion, supporting peace and improving awareness of the cultural rights of traditional peoples on all continents. This move is helping in making the cultural question a legitimate global concern.

The understanding of the mediations and meanders that articulate national legal and political realities to these international and multilateral spheres is no simple task to be faced by researchers and policy makers. Norms and priorities decided upon in those extra-national fora do not automatically become actual practice in every country, since biases and filters act in both directions. The countries' representatives do not mechanically echo the internationally accepted discourses, but have to deal with the difficulties of putting these words into practice; the international and multilateral fora often function as arenas where not only national, but often regional or sub-regional antagonisms are in dispute and where hegemonies are formed. This question does not regard governmental agencies alone; NGOs have to face similar challenges, and so do the affected cultural communities that re-elaborate, in their own terms, the possibilities and resources made available by those negotiations.

National experts and other social agents, such as state bureaucrats and technical personnel, act as brokers and interpreters in this multiple cultural translation process, bringing to the table their varying capacities to respond - in the required speed and proper technical language - to the demands of the processes that are set in motion in this multi-institutional sphere. 


\section{Institution building processes in context}

The creation of the Brazilian federal preservation institution, the Instituto do Patrimônio Histórico e Artístico Nacional (IPHAN), dates from $1937 .{ }^{1}$ It was implemented by a sector of the modernist intellectual elite, in the fissures of the authoritarian and nationalistic régime known as the Vargas Period. ${ }^{2}$ IPHAN has greatly influenced the preservation activities in the country, which became systematically institutionalized at the state and municipal levels from the late 1960s and 1980s, respectively. The social rooting of this policy and its critical appreciation by the academic community, particularly in questions regarding its implications for the politics of identity and difference in the country, is still incipient. ${ }^{3}$

Although in Brazil systematic research on heritage has been practically limited to the fields of archaeology, art history and architecture, and secondarily, to the formation of Iphan as a governmental institution, the economic, political and ethical consequences of these policies increasingly motivate research and professional activity in the social sciences. It is a welcome fact that cultural heritage is gradually becoming a significant target for graduate research and expertise in social anthropology, involving manifold interests and perspectives, particularly those of cultural activists and intellectuals engaged in the democratization process of the country. ${ }^{4}$

As mentioned previously, IPHAN was designed and its institutionalization was implemented by a group of modernist writers, artists and architects ${ }^{5}$

1. Federal Decree 25, November 30, 1937, organizes the protection of national historic and artistic heritage in Brazil.

2. Getúlio Vargas sized power as chief of the provisional government in 1930, was elected president in 1934, dissolved the Congress in 1937, ruled the country until deposed from office in 1945, was re-elected to the presidency in January 1950 and ruled the country until 1954.

3. The Revista do Patrimônio Histórico e Artístico Nacional published many significant contributions in this field. The 2005 edition, issue number 32, is a thematic issue on Patrimônio Imaterial e biodiversidade.

4. In the 2006 biannual meeting of the Brazilian Anthropological Association, for instance, there were three special round tables, several workshops - one of which with 30 presentations - and several individual papers dedicated to the theme; this represents a significant increase in the number of researchers interested in the subject if compared with previous ABA meetings.

5. Writers such as Mario de Andrade, Carlos Drummond de Andrade and Manuel Bandeira, as well as architects such as Lucio Costa and Oscar Niemeyer, among other prominent intellectuals of the time, gathered around Rodrigo Mello Franco de Andrade in the designing and implementation of IPHAN for more than 3 decades. 
in a conjuncture of national affirmation of the country that may have strengthened the official nationalism implemented by Vargas' dictatorial regime, but was surely not instrumental to it as I have argued elsewhere. (Arantes, 1997: 278 passim) Putting in a short and necessarily blunt statement, the main question faced by the preservation agenda of the early days of IPHAN was to identify, protect and promote the documents of Brazilian art and history, as well as the country's cultural contribution to western civilization, rather than celebrating local symbols for the sake of being national. ${ }^{6}$

From the mid 1980s onwards, there was a significant growth of social movements on the basis of claims regarding civil rights, housing and quality of life in urban settlements. In such a conjuncture, Brazilian preservation agencies faced an important increase of demands regarding, among other things, the recognition and protection of the arts and crafts developed by the popular classes, particularly African Brazilians and indigenous peoples, as part of national heritage. What became clearly at stake was the inclusion of these strata in full citizenship and in the formal political process. Such demands motivated a critical review of the values embedded in heritage policy and promoted by it. The following figures indicate the magnitude of the responsibilities accumulated by the Brazilian federal preservation institution in the 67 years that preceded the implementation of the policy specifically designed for safeguarding intangible cultural heritage: 79 urban sites ( 8 included by Unesco in the World Heritage List), implying some 21,000 buildings in approximately 61 cities; 18 natural and 7 archaeological sites (respectively 8 and 2 included by Unesco in the World Heritage List); 802 individually registered buildings, among other items.

The safeguarding of intangible cultural heritage was recently introduced as a systematic public policy in Brazil, as well as abroad. Its roots go as far back as the late 1970s, in the context of the democratization process after the 1964 military coup. Since the late 1980s, the social movements have become more diversified, there has been a clear increase in their legitimacy as regards public opinion, and they have grown considerably in number of adherents and supporters. Administrative, financial and political investments also have become more substantial. The Brazilian Constitution of 1988 resulted from strong participation by civil society and it significantly consolidated a democratic approach to issues related to cultural rights

6. The tension between the singularity and universality of Brazilian cultural heritage as protected by IPHAN is one the main themes of the doctoral dissertation of M.V. Motta Santos (1992, University of Brasilia). 
(intangible heritage included), environmental conservation and sociobiodiversity. These became part of the reality to be managed by cultural policy markers in the field of preservation. At present, it is inescapable to deal with "traditional knowledge and traditional cultural expressions," to use the terminology adopted by WIPO, in the field of heritage in Brazil, as happens in many other countries of the developing world. Another important consequence was that the institutional mission of IPHAN had to be reinterpreted and new legal and administrative procedures, as well as specific protection instruments, had to be created and put into practice in order to respond to the new tasks as determined by the 1988 Constitution.

That legal text defines in Article 216 that

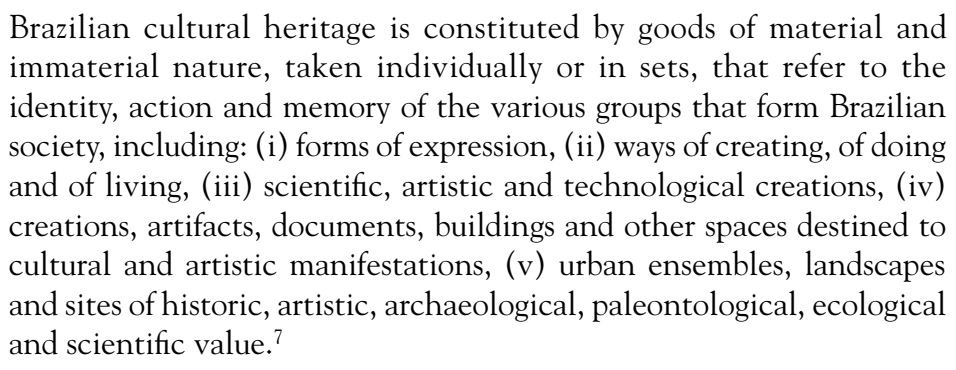

The Brazilian constitutional text innovates in several important senses. First, it honors the understanding that nation is a plural, internally diversified and socially heterogeneous reality; second, it includes both material and immaterial cultural goods in the domain of heritage; and third, it highlights not only the exceptional historic or aesthetic quality of cultural items, but their social significance to the groups that form the national community, as it brings up the question of their reference to actual social issues such as those groups' identity, action and memory; and 'talking about 'cultural references' presupposes subjects to whom such references make sense (references to whom?)." (Londres Fonseca, 2000: 59) Thus, the legitimate subjects of right implied by this legal text are no longer the intellectual hegemonic elite and their extraordinary deeds, but a politically welcome social entity, although difficult to handle by policy makers, phrased as the various groups that form Brazilian society. It specifically nominates among these indigenous peoples and African descendants. So, the way was opened to legal cultural claims based on the perception and affirmation of social and political difference, and of the cultural rights attached to them.

7. My translation.

8. My translation. 
The specific legal instrument for the implementation of the intangible heritage policy in Brazil is the Federal Decree 3551, of $4^{\text {th }}$ August 2000. It creates the administrative processes of inventory making and registry as well as the national program for safeguarding intangible cultural heritage. Presently, there are four registry books for the classification of immaterial heritage, namely, (1) knowledge and ways of doing, (2) forms of expression, (3) celebrations and (4) places. The creation of other books is made possible by that legal instrument and, in fact, there is presently a movement towards the creation of another one, dedicated to orality and to the various languages spoken in Brazil.

Forms of expression, knowledge and technology, collective celebrations and the social production of place - not to mention language and orality - are defined as objects for safeguarding by the existing legal texts (the Brazilian legislation as well as Unesco`s Convention, among others) as far as they are living realities, concerning specific human groups. Although the legal instrument dates from 2000, the institutional changes that made its implementation viable date only from 2003. So the institutional experience of IPHAN on this matter is still incipient, but surely effective. Up to the present date, the following items have been registered as Brazilian intangible cultural heritage: forms of expression (Kusiwa art: Wajãmpi body painting and graphic art, Samba de roda from the Recôncavo, Jongo da Serrinha), ways of doing (Culinary knowledge of the bahianas, Construction of viola-de-cocho, Cooking pottery from Goiabeiras), celebrations (the Cirio Festival of Our Lady of Nazareth).

\section{Culture as officially protected heritage: from diversity to difference}

These new legal parameters have produced - and are producing significant consequences in the formulation and implementation of public policies in the field of heritage. The legal and administrative changes at the federal level induced some States and Municipalities to take measures regarding the protection of cultural artifacts and practices considered relevant at those levels.

An important social and political outcome of the safeguarding of intangible cultural heritage is that these changes affect the value attributed to what is identified as worthy of official protection, and perhaps most importantly, the relative position of the agencies involved, particularly the role and authority of local communities in the identification of what should officially become heritage and in the implementation of specific 
protection practices. This issue asks for deeper consideration.

The inclusion of a specific cultural item as heritage in the domain of official public culture is a decision taken by the State, as representative of the public interest at the federal, the state and the municipal levels. This decision is technically supported by academic knowledge about the item in question, and it is legitimized by a council of representatives of civil society grounded in their intellectual authority, within the parameters set by the existing legislation.

The adoption of the idea of cultural reference by the Brazilian legislation and preservation practices as a legitimate source of value to be taken into consideration in the identification and proclamation of a cultural item as heritage, and its inclusion alongside with the recognition of the exceptional quality of the preserved object as a historical testimony or work of art, add an important ingredient to the arenas in which such negotiations take place. Indeed, it affects positively the strategic positioning of the cultural communities vis-à-vis the traditionally elitist bias of the procedures adopted in the decision making process by the preservation institutions.

This question has become highly politicized. In the case of the Brazilian legislation, as in the UNESCO convention of 2003 and in a recent experts' meeting, ${ }^{9}$ the local cultural communities' authority was explicitly evoked and recognized in the preparation and presentation of candidacies and in implementing the safeguarding of action plans. In other words, their authority in terms of knowledge, their self-determination in terms of building political strategies and deciding about priorities and their condition as protagonists (or at least active participants) in the safeguarding plans became explicitly and officially reinforced.

Particularly in the case of intangible cultural heritage, the process leading to heritage building results from complex and often tense negotiations involving cultural mediators who are internal and external to the social groups to which the cultural asset is primarily relevant. Examples of such intermediaries are the communities' representatives, office holders and cultural custodians; or the technical and administrative institutional personnel, the independent experts and political activists that participate in the institutional practices; as well as the entrepreneurs and market experts interested in developing business opportunities on the grounds of

9. Convention for the Safeguarding of Intangible Cultural Heritage, adopted by UNESCO's 32nd General Assembly in 2003, and Unesco-ACCU Expert Meeting on Community Involvement in Safeguarding Intangible Cultural Heritage, Tokyo, 13-15 March 2006. 
such assets. What is submitted to the preservation councils' decision is, in one way or another, permeated by such negotiations. As the items proposed for preservation became less orthodox - i.e., including not only artifacts, but also intangible items, and not only those referring to high culture but also an increasing number of references that primarily concern popular cultures - more intense and passionate became the discussions regarding their inclusion in the heritage lists.

The Brazilian example suggests that cultural heritage has become a more complex issue of culture and politics in our time than it was in the heyday of the preservation institutions, and this has a lot to do with the politics of intangible cultural heritage. In other words, the inclusion of intangible culture in the realm of preservation clearly revealed the fact that heritage - goods of intangible nature, as well as artifacts, monuments and sites - belongs to communities and is embedded in the social and cultural processes by which their social lives evolve and are transformed. Thus it is inevitable to recognize that safeguarding - as a public policy - directly interferes with social processes that (1) take place in the present, not in the past, and (2) are developed by real and specific human collectivities, not by nations in the abstract.

The underlying political premise of the queries and disputes in this field is that cultural pluralism is the main treasure to be preserved and that to maintain a creative and dynamic cultural diversity should be the raison d'être of such policies. From an anthropological point of view, on the other hand, it is not surprising that social movements, particularly those rooted in the struggle for cultural rights, have stepped forward to discuss which and whose "cultural references" (to name the object under discussion according to the Brazilian Constitution) would be inventoried, identified and protected, along with the method to be used, and at the same time, to reinforce their own self-esteem, regardless of any other.

Remembering Foucault, it is worthwhile bringing up at this point the thesis that the enforcement of power generates counter-powers and that customary cultural practices do not passively absorb realities imposed from the outside, such as would be the case in the present context, for the values and legitimacy attributed by external preservation institutions, or denied by them in the case of refusing their proposals. Cultural communities tend to reinterpret and appropriate external input in terms of internal cultural dynamics, often transforming signs of cultural diversity into manifestations of difference in the political sphere. I draw this distinction from $\mathrm{H}$. Bhabha's argument: 
[Cultural difference, he writes] is a process of signification through which statements of culture or on culture differentiate, discriminate, and authorize the production of fields of force, reference, applicability, and capacity. [...] The concept of cultural difference focuses on the problem of the ambivalence of cultural authority; the attempt to dominate in the name of a cultural supremacy which is itself produced only in the moment of differentiation. (Bhabha, 1988: 18-19)

It follows from that argument that, given the fact that safeguarding motivates and, in the limit, sets in motion cultural changes that are neither totally foreseeable nor controllable, one crucial challenge to preservation is to create mechanisms by which the designing and evaluation of policies and programs, as well as the allocation of financial resources, is shared with the affected cultural communities. This shift means a decisive step forward in relation to "participation", as a motto that in the 1980's mobilized the cultural political debate in Brazil. The question then was to provide access for the popular classes to a decision making process that by definition was external to them; today, what is at stake is the recognition of the popular strata as legitimate protagonists of the culture policy, side by side with the government's and the elite's institutional agents. The key issue regarding the efficacy of heritage policies became, then, the nature and quality of the relationship established between the external and the local social agencies.

Today, there is more consensus and acceptance of those changes, both in public opinion and among preservationists. But tensions and negotiations between the agencies involved (internal and external) should still be considered as an embedded characteristic of cultural heritage. This is an active force that should be constantly taken into consideration and dealt with by the safeguarding practices, regardless of the fact that the resources that support them are public or private.

The speed at which these changes are being consolidated, as well as the technical and legal consistency and refinement of the instruments that were recently devised are noticeable; and there are reasons for that. They owe a great deal partly to IPHAN's solid institutional experience in the field of preservation before the institutionalization of intangible cultural heritage, but mainly to the quality and volume of the ethnographic research available about popular and indigenous cultures, that has been accumulated in the country as well as abroad, on topics that are relevant to what is now called 'Brazilian intangible cultural heritage'. 


\section{Heritage as an asset in market economy}

The conceptual and practical changes in focusing this paper bring explicit ethical and political challenges regarding the social responsibility of the governmental institutions and their agents vis-à-vis the cultural communities affected by these policies. Cultures are living and changing realities which depend on specific conditions for their production, continuity and change. As a consequence, the sustainability of safeguarding policies becomes a key issue in the present discussion. This notion has been incorporated in the practice and discourse of environmental conservation since $1987,{ }^{10}$ and it may be useful to recall that it was derived from a very simple, clear and sensible ethical principle, i.e., that sustainable development is the one that satisfies contemporary basic human needs without depriving or expropriating future generations. It is about time that this subject is brought to the context of cultural preservation.

This is a particularly relevant issue because it is becoming part of the common sense understanding among social policy makers that the protection and enhancement of heritage may contribute to social and economic development. This is a particularly strong view among those who claim that globalization creates new economic opportunities for local lives. Some ongoing social programs, although still incipient, seem to corroborate the notion that safeguarding intangible cultural heritage may be a cornerstone for human development and mutual understanding; but if it is true that market economy - and globalization in particular - opens new perspectives for the appropriation of traditional cultural resources, it is also a fact that it presents new challenges for the heritage's custodians and practitioners. The implications of this statement should not be dismissed by cultural policy makers.

Cultural heritage identified by preservation agencies as being distinctive to specific social groups and, for such reason, worthy of safeguarding, are often - or tend to become - assets for the production of consumer goods and services. As a consequence, they become part of wide and complex systems of circulation of people, signs and capital and entangled by them. These circuits operate on multiple scales and establish network connections that impose upon the local cultural communities' demands that may be in conflict with their social organization, besides putting pressure on the natural resources used by their traditional practices.

10. Cf. the Brundland Report. 
Frequent questionings in relation to the effects of market economy on handmade crafts, for example, have to do with the fact that it tends to increase the volume of production, to impose the standardization and continuous availability of products, as well as the adaptation of designs and materials to the tastes and needs of consumers that live far from the social boundaries of the producer communities and do not share their values and worldviews. So, the new demands tend to be established by dealers and by other agents external to the local groups, without much or any participation by their members. Such absence of direct negotiation and shared cultural experience between producers and final consumers strengthen the power and legitimacy of market intermediaries (brokers) as agents in this process, producing major consequences for the work processes, for the social relations that give meaning and context to these practices and for the environment, as far as the availability of raw materials is concerned. Globalization aggravates this process since, as is clearly indicated by the present growth of tourism, it increases the development of senses of place of all sorts, particularly of historical settings used for mass consumption, as I have argued elsewhere (Arantes, 2000: 93 passim).

The symbolic production of senses of place and of identity does not necessarily stem from the clear-cut opposition between inner and outer social realities regarding a social group. Particularly when and if intercultural aesthetic appreciation is at stake, as is the case in tourism and in various sectors of the cultural industry, so-called hybrid cultural patterns often bridge cultural differences. Permeable and flexible borders are produced through the articulation of signs of mixed origins and nature. This is perhaps one of the most prominent characteristics of contemporary cultures: they predominantly do not claim to be pure, but hybrid in nature, not walls, but bridges to be crossed by those who know the right codes of identification.

\section{The uses of heritage in Bahia}

In order to clarify some points that raise relevant questions for the political economy of heritage, I would like to refer to concrete examples. In the context of rapid increase of investments in tourism and in real estate associated with heritage sites, the popular celebrations of Southern Bahia became a significant source of income for local economies. These festivities are rituals of popular Catholicism that celebrate patron saints or special dates of the religious calendar, accomplishing the important role of reinforcing the local communities' social structure, the sense of belonging of the group members and, consequently, they constitute the main arenas 
for the negotiation of prestige and staging social stratification.

In the village of Trancoso, which is one of the best known sites of that region, the celebration of San Sebastian takes place around January 20 and is the peak of the year's festivities calendar. ${ }^{11}$ Trancoso is a small village with a population of approximately 5,000 people, according to the census of 2000. The present-day village occupies the site of an old Jesuit settlement built around 1558 to protect the Portuguese territory and to gather and Christianize the local indigenous population. It remained as a distant and unspoiled seaside spot in the south of the Porto Seguro municipality until the mid 1980s, when the population started to change and grow fast, as happened with its economy and celebrations. Between 1991 and 1996, for example, the total population of the Porto Seguro municipality grew from 34,660 to 64,957 people, that is, $87.41 \%$ in 5 years! Today, Trancoso includes new residents, who are mainly young people who come from many Brazilian cities and foreign countries, looking for new lifestyles and business opportunities, both licit and illicit. Others, such as politicians, professionals and media celebrities, also return every season to the village as regular visitors.

It is crucial for the newcomers' inclusion in local life (politics and economy notwithstanding) that they be accepted as active participants in such celebrations. More recently, religious disputes have also become part of the game. Catholic priests, who have recently returned to the region, try to take control of the San Sebastian celebration, claiming that popular Catholicism should be subsumed under the official activities of the church. The evangelical ministers, being stricter, argue that such celebrations should not take place since they are not acceptable expressions of Christianity!

Yet, despite this conflictive situation - which is part of the local cultural scene - the rite has not lost its traditional meaning. Although only the best known local families living in the central square of the village are the official celebration organizers, new rules and ad hoc criteria have been adopted making it possible for outsiders to participate in the preparation of the ceremony by giving suggestions as to the decoration of the site or contributing money, providing beer, sugar cane brandy, meat or the wood for the celebration pole which is remade every year.

But as the accommodation of costume to circumstance has limits, whereas some specific areas of the ritual were opened to the new community

11. For more information about the San Sebastian Celebration in Trancoso, see Andrade \& Arantes, 2000 (v. 1, 291-355). 
members, others were kept as exclusive to the traditional families. These are the fixing of the meals, the performance of music and of a specific choreography, decorating the pole and painting the celebration flag. These were kept as prerogatives of those bound by birth to the large kinship groups that form the sociological nucleus of the native community, reinforcing their role as protagonists of the whole process in the local political arena.

The example is quite suggestive of several issues related to the politics of intangible cultural heritage. In the first place, it shows that some aspects of a complex social institution can be less permeable to innovation than others. Charged with a stronger sense of local identity, the changes make the cultural performance stronger as an active symbol of the community, mirroring what the group considers as "tradition" and, for that matter, one that "belongs" to them. The incorporation of new circumstances was also a means of strengthening heritage as a sign of historical continuity, social and personal identity and self-esteem.

It is also relevant that the so called "traditional" manifestations of community life seem to have some degree of ambiguity. Although considered as one of the dearest and most singular symbols of community life, this celebration did not exclude outsiders but was made partially accessible to them. In my view, such porosity or partial accessibility is a key attribute of items proclaimed as cultural heritage. In the context of radical change in scale, from being part of a closed ceremonial life based on kinship to becoming a global event, such rituals incorporate new social actors in the social structure and symbolically make way for the constitution of a ritual of continuity. Yet, innovations do not necessarily destroy the aura on which depends the verisimilitude of such performances for insiders and outsiders alike. Indeed, a hard core of local knowledge protected by customary structures of power and a buffer zone of soft and permeable edges, such seems to be the structural characteristic that forms the basis of the relative strength of some enduring heritage practices that might have otherwise disappeared in the recent years of intense social change.

It should be pointed out that this celebration was not proposed for proclamation as official Brazilian cultural heritage. Its bearers and practitioners keep control of the performance, thus feeding the historical continuity of the rite, safeguarding it in their own way and for their own purposes. Consequently, this example mainly illustrates that cultural communities have their ways of dealing with the past, as well as with the future of their cultural references. 
However, this is not always the case. Very often, State support is asked for and is, in fact, needed to help counterbalance the disruptive effects of the processes of change that affect the organic cultural development of specific communities. The samba-de-roda, registered as Brazilian Cultural Patrimony and proclaimed by UNESCO in 2005 as a masterpiece of the oral and immaterial heritage of humankind, is a case in point. Well known as a Brazilian national symbol, the samba could be seen as a superfluous item to be officially protected, given its immense popularity and the private investments made both by the entertainment industries in the development of new styles and variants, and by researchers in documenting traditional sources. As a musical genre, it is widespread in the country as a whole; as cultural reference, however, it was identified and located in a few communities living in an area known as Recôncavo, in the region of Salvador, the capital city of the State of Bahia. In those localities, there are several musical groups who still perform and pass on to their children the samba de roda, a style that is the closest known living manifestation of the genre that gave birth to the urban variants that became icons of national culture. As C. Sandroni clearly argues in the candidature file submitted to UNESCO's jury, without official protection, the instruments, choreographies, narratives and ways of transmission practiced by its performers would certainly be soon lost and leave no trace for future generations, as today's youngsters are interested almost exclusively in the styles that are sold and legitimized by the mass media (Sandroni, 2005).

\section{Heritage and the popular culture debate}

The examples chosen for the present text, as well as the recently accumulated experience of IPHAN on these matters, might misleadingly suggest that there would be an intrinsic and natural association between intangible cultural heritage and popular cultures. Immaterial heritage is not exclusively associated with the popular classes and ethnic groups, as monuments and sites are not distinctive of the elite and upper classes. There are some questions in this area that ask for urgent discussion. So, even if briefly, I would like to at least mention some of them in the present context.

In Brazil, as well as in other parts of the world, to give precedence today to the protection of popular cultures in the implementation of this new policy is almost inevitable. In the first place, it is a historical responsibility in the face of the accumulated biases of the policies that have so effectively endowed the ruling elite by treasuring their monuments and works of art and promoting them as national symbols. Another reason is the state of fragility 
of so much knowledge and human experience that lie unregistered and precariously safeguarded by communities' custodians and practitioners who frequently live in adverse circumstances and extreme poverty; safeguarding culture, in these situations, may also be a form of humanitarian action. These reasons become still more pressing and convincing if one is reminded that social cohesion, self-esteem and senses of identification with wider political communities such as the ethnic group or the nation are very deeply rooted and dependant on aspects of heritage where the local, the popular, the national - and sometimes the global - meet.

The protection of intangible aspects of "popular culture" empowers historically marginalized segments of society which, reflexively can put forward, on the basis of the authority granted by the proclamation of their culture as heritage, claims to territorial rights, to the protection of shrines and other sacred places threatened by unplanned economic and urban growth, and so forth.

What was called in Brazil "the national-popular question" comes back today with new contours. In the 1950s and early 60s, the ideological aspect of the question was the issue at stake. The empirically observed common people's culture (urban or rural) was considered rough, backwards and reactionary by the political avant-garde of the time, and the cultural industries production as alienated and alienating. So the mission of the 1960s enlightened intellectual was then to criticize, transform and develop popular cultural reality, giving way to the formation of a revolutionary conscience. This view found itself strongly criticized in theory as well as in practice by the Brazilian left, particularly regarding the outcomes of the popular struggle against the military regime. In the late 1970s and early 80s, the popular culture issue was revitalized, with the emergence of the social movements that put in motion the re-democratization of the country. In such a context, the prevailing understanding was that culture is embedded in social life, not a reflex or distorted manifestation of it. Consequently, issues soon at stake were its contradictions, the conditions of its production and reproduction in relation to social identity, inequality and diversity. These were the conceptions that informed the lobbying groups that were active in the Constitutional Reform of 1988 and that re-emerged in the present process of safeguarding intangible cultural heritage.

The politics of popular culture today has to deal with a tension that arises from the fact that knowledge, forms of expression, places, festivities, artefacts of various kinds - from archaeological findings to artworks, buildings and public monuments - as well as landscapes are recognized 
as relevant identity icons and as economic assets. This tension between politics and the market permeates heritage as a multi-faced reality - be it popular or elitist, tangible or intangible - and has to be dealt with by the academic experts, the local leaders and the public servants engaged in reinterpreting them, both textually and in the practical decisions affecting this protection, reproduction and change.

\section{Bureaucrats, experts and community leaders as cultural mediators}

One last aspect worthwhile pointing out in closing this presentation is that the official agents of safeguarding policies participate in local life in ways that are similar to those of the mediators and newcomers mentioned in the various situations focused on by this paper. The objects chosen for official safeguarding tend to be those praised by cultural communities as their own treasures, as sacred, fragile and deeply rooted in social structure. They are as well targeted by safeguarding institutions and cultural policy makers, as they are also highly cherished by the market of cultural commodities.

Consequently, it becomes extremely relevant to critically face and evaluate the consequences of the interference that safeguarding produces in local life, as well as to understand to what extent it is desirable and desired by the local community. The positive and negative consequences of these policies must be technically monitored, and the terms of the negotiations established between civil servants, acting in the name of public heritage institutions, and the local communities must be clearly and explicitly established, in accordance with the ethical parameters of the best professional practice.

These are some of the questions faced by the politics of safeguarding intangible cultural heritage today and to which the dialogue among academics, policy makers and cultural communities may provide useful and practical clues. 


\section{References}

Andrade \& Arantes Ltda, 2000, Inventário de Referências Culturais do Museu Aberto do Descobrimento. Brasília: Iphan.

Arantes, Antonio A., 2000, "Paisagem de história: a devoração dos 500 anos." In Projeto História: os sentidos da comemoração, 20: 63-96. São Paulo: Educ.

Arantes, Antonio A. 1997. "Patrimônio cultural e nação." In Angela Araújo (ed.), Trabalho, cultura e cidadania: 275-290. São Paulo: Scritta Bhabba, Homi, 1988, "The commitment to theory." New formations 5: 5-23. Londres Fonseca, Maria Cecília, 2000, "Referências culturais: bases para novas políticas de patrimônio.” In GT Iphan (ed.), O registro do patrimônio imaterial: 50-74. Brasília: Iphan.

Motta Santos, Mariza Veloso, 1992, O tecido do tempo: a idéia de patrimônio cultural no Brasil (1920-1970). Unpublished thesis: University of Brasilia.

Sandroni, Carlos, 2005, Samba de roda do Recôncavo Bahiano. Candidature File for the Third Proclamation of the Masterpieces of the Oral and Intangible Heritage of Humanity. 